\title{
Jacques Lucien Monod (1910-1976): Co-discoverer of the operon system
}

\author{
Siang Yong $\underline{T a n}^{1}$, MD, JD, Jill K $\underline{\text { Furubayashi }}{ }^{2}$, BS
}

One of the great problems of philosophy is the relationship between the realm of knowledge and the realm of values. Knowledge is what is; values are what ought to be. I would say that all traditional philosophies, up to and including Marxism, have tried to derive the 'ought' from the 'is'. My point of view is that this is impossible, this is a farce.

- Jacques Lucien Monod

$\mathrm{P}$ assionate about the advancement of science, Dr Jacques Lucien Monod devoted his life to the discovery of knowledge. His contributions to molecular genetics are extraordinary. However, science was only one of his many pursuits. This Nobel laureate was also a cellist, mountaineer, yachtsman and philosopher, and his varied interests paralleled his complex personality. Monod was born on 9 February 1910 in Paris, France, to Lucien Monod, a French artist, and Sharlie MacGregor, an American. When he was seven, the family moved to Cannes in southern France, where Monod lived until he went to college. His father read Darwin, loved music and art history, and was described as a free-thinker. Sharing his father's love of music, Monod learned to play the cello as a child and often performed chamber music in the family's home,

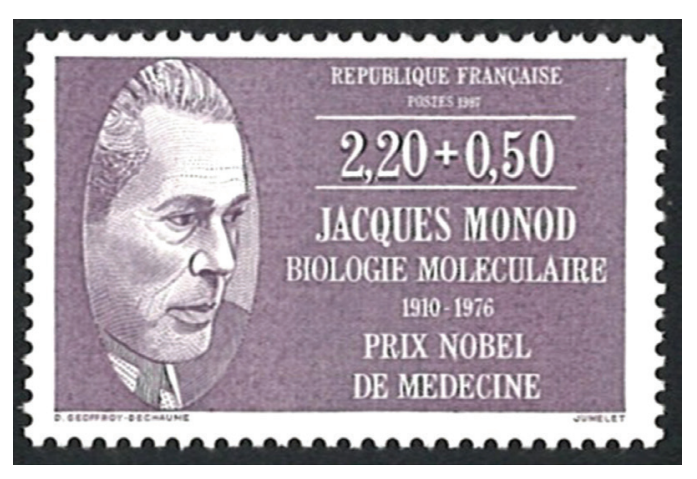

Monod spent the early years after graduation in a laboratory that studied ciliates and joined an expedition to Greenland in 1934. While he was preparing for a second Greenland expedition in 1936, Boris Ephrussi, another researcher that he met at the Marine Biological Laboratory in Roscoff, encouraged him to abandon the Greenland expedition for a fellowship at the California Institute of Technology (CIT), California, USA. With Ephrussi's assistance, Monod obtained a Rockefeller Fellowship, which funded the year-long position. It was a fortuitous decision that literally saved his life. The Greenland expedition that he turned down was lost at sea.

While at CIT, Monod studied physiological genetics under Thomas Hunt Morgan, the Nobel laureate of fruit fly (Drosophila) fame. There, he was awestruck by how ideas were freely shared among researchers. Unlike the hierarchy in the French scientific community, CIT promoted open discussions between inexperienced scientists and veteran researchers, a progressive environment that was reminiscent of Monod's childhood home. He adopted these ideals and later attempted to recreate a similar intellectual environment when he directed the Pasteur Institute in Paris.

After completing his fellowship, Monod returned to the Sorbonne to Clos Saint Jacques. As he grew older, his interest in music shifted. He started a Bach choir in Paris and even contemplated a career as a conductor. In addition to music, Monod also enjoyed rock climbing and sailing, unexpected hobbies for a young boy whose leg was weakened by polio.

STUDIES AND EARLY CAREER Early exposure to his father's Darwin books sparked Monod's interest in science. After completing his secondary education at the Lycée de Cannes, Monod moved to Paris and began his studies at the Sorbonne in 1928. He spent three years learning basic sciences, including biology, chemistry, geology and zoology. During the summer, he traveled to Roscoff, Brittany, France, to study at the Marine Biological Laboratory. This experience exposed him to some of the most influential scientists of his time and supplemented the outdated science education he was receiving at the Sorbonne. Monod credits Dr André Lwoff, one of the researchers he met in Roscoff, with his initiation to the powers of microbiology. He graduated with a science degree in 1931. pursue a doctorate in the natural sciences. Under his mentor Dr Lwoff, he began studying the growth rate and yield of the bacterium Escherichia coli (E. coli). In 1941, Monod completed his doctoral thesis, Recherchés sur la croissance des cultures bactériennes ('Searches on the growth of bacterial cultures'), which detailed the effects of nutrient limitation on bacterial replication.

BRIEF INTERLUDE In 1938, Monod married Odette Bruhl, an orientalist, an archeologist and a Jew. During the Nazi occupation of France in 1940, Monod, his wife and their twin sons fled to the French countryside, and he later joined the underground resistance in Paris. This dangerous position resulted in his arrest by the German Gestapo. Monod narrowly escaped but continued working for the resistance movement. However, he had not wholly abandoned science during this period, occasionally travelling to Dr Lwoff's laboratory to conduct experiments. Following the liberation of Paris, Monod joined the French communist party, moved his family back to the city and 
returned to the Sorbonne. He earned several military honours for his service in World War II, including the Croix de Guerre and the American Bronze Star Medal. His wife Odette went on to become the curator of the Guimet Museum in Paris.

MOLECULAR BIOLOGY In 1936, Dr Lwoff offered Monod a position in his department at the Pasteur Institute. There, Monod continued his work with E. coli and established relationships with other scientists. The most notable of these was Dr François Jacob, a prodigy of Dr Lwoff's, who had worked on bacteriophage, mechanism of bacterial conjugation and the direct transfer of genetic material by cell-to-cell contact. Dr Jacob and Monod's partnership proved to be particularly productive. The two combined their individual and unique expertise to elucidate the mechanism of regulation of genetic expression. Monod capitalised on his doctorate work on the differential growth of $E$. coli when exposed to two different sugars - lactose and glucose. Glucose is the preferred substrate for the organism, and when both glucose and lactose are available, the enzymes for metabolising lactose are suppressed. Only when the supply of glucose has been exhausted does $E$. coli start to synthesise the enzymes necessary for metabolising lactose.

Dr Jacob and Monod probed this phenomenon at the molecular level. They proposed that genes called operons coded for proteins that could inhibit their expression and described how DNA contained these regulatory genes, which were transcribed as mRNA to regulate protein synthesis. They coined the term negative gene regulation, deriving their powerful conclusions from experiments using the lactose operon (lac operon) system. In 1961, they published their sentinel discoveries in an article entitled 'Genetic regulatory mechanisms in the synthesis of proteins', which earned Dr Jacob, Monod and Dr Lwoff the 1965 Nobel Prize in Physiology or Medicine. Elated by the culmination of his life's work, Monod described the discovery as the "second secret of life". He even bravely postulated, "Anything found to be true of $\mathrm{E}$. coli must also be true of elephants." In addition to the Nobel Prize, Monod's remarkable work in molecular biology earned him numerous awards, honorary degrees and membership in some of the most acclaimed scientific organisations, including the Royal Society, National Academy of Sciences and American Philosophical Society.

'CHANCE AND NECESSITY' After receiving the Nobel Prize, Monod was named chair of the Collège de France in 1967. In addition to his new academic duties, Monod spent time writing about the philosophy of biology and evolution. These controversial works were later published in the novel Le Hasard et la Nécessité ('Chance and Necessity') in 1970. The novel became a bestseller in both the United States and France. Believing that "the first scientific postulate is the objectivity of nature: nature does not have any intention or goal", Monod advocated in his book the complete disavowal of value judgements when assessing truth. This 'ethics of knowledge' was in direct opposition to the entrenched philosophical and religious reliance on morality then. Monod's atheistic conclusion was that "man at last knows he is alone in the unfeeling immensity of the universe, out of which he has emerged only by chance. His destiny is nowhere spelled out, nor is his duty. The kingdom above or the darkness below; it is for him to choose".

OTHER CONTRIBUTIONS The following year, Monod was appointed director of the Pasteur Institute, which was facing the consequences of decades of financial mismanagement. Fearing impending bankruptcy, Monod spent the final years of his life helping the organisation to circumvent governmental control. He was described as 'authoritarian and inflexible' as he restructured the institute and forced several accomplished research heads into early retirement. In contrast to this unkind perception, Monod was said to be extremely generous and benevolent to laboratory technicians and ancillary staff, which earned their loyalty. Monod also helped several individuals escape communist and fascist governments. Unfazed by controversy, he led the movement to legalise abortion in France, serving as president of the Mouvement français pour le planning familial, the French movement for family planning. Prior to the legalisation of abortion in France in 1975, Monod often gave money to those who privately contacted him for help.

DEATH AT 66 In 1972, one year after the death of his wife, Monod contracted viral hepatitis and, subsequently, aplastic anaemia. By 1975, he was very ill and kept alive by repeated blood transfusions until his death on 31 May 1976. A memorial service for Monod was held at the Royal Society, where his friend and mentor, Dr Lwoff, chronicled his scientific career. He was buried in the Cimetière du Grand Jas in Cannes on the French Riviera.

\section{BIBLIOGRAPHY}

- Hess JC. French Nobel biologist says world based on chance leaves man free to choose his own ethical values. New York Times 1971 Mar 15; 6 .

- Jacob F, Monod J. Genetic regulatory mechanisms in the synthesis of proteins. J Mol Biol 1961; 3:318-56.

- Wikipedia. Jacques Monod. Available at: https://en.wikipedia.org/wiki/ Jacques_Monod. Accessed August 28, 2018.

- Kyle RA, Shampo MA. Jacques Monod--molecular biologist. Mayo Clin Proc 1990; 65:129.

- Monod J. Chance and Necessity. 1st ed. New York: Alfred A Knopf, 1971: 180

- Raju TN. The Nobel chronicles. 1965: André Lwoff (1902-94), François Jacob (b 1920), and Jacques Monod (1910-76). Lancet 1999; 354:434.

- Stanier RY. Jacques Monod, 1910-1976. J Gen Microbiol 1977; 101:1-12.

- Ullmann A. Origins of Microbiology: A Tribute to Jacques Monod. Washington, DC: ASMPress, 2003. 